\title{
Perspectivas jurídico-canónicas para la protección del patrimonio cultural eclesial en Colombia*
}

\author{
Legal-Canonic Perspectives for the Protection of the Ecclesial Cultural Heritage in Colombia
}

Sandra Lidia Flórez
sandralidiaflorez@yahoo.es
ORCID: https://orcid.org/0000-0002-6498-899X
DOI: https://doi.org/10.11144/Javeriana.ucan35-51.pjcp

Recibido: 18 Junio 2018

Aceptado: 07 Julio 2018

Publicado: 30 Diciembre 2018

\section{Resumen:}

Este artículo busca mostrar la importancia que ha tenido el patrimonio cultural eclesiástico en la labor de la Iglesia, su evolución histórica y su desarrollo legislativo en materia tanto eclesial como civil.

La sociedad actual ha ido estableciendo diferentes marcos legislativos civiles para su protección, elementos que deben ser aprovechados por la Iglesia, según el llamado de los romanos pontífices en los últimos tiempos. Por este motivo, se quiere dar a conocer herramientas legislativas tanto en el derecho civil como en el canónico que permitan una mayor eficacia en la protección de este patrimonio, referido principalmente al caso colombiano.

Palabras clave: bienes culturales, bienes eclesiásticos, Colombia, protección legal.

\section{Abstract:}

This article aims to show how important the ecclesial cultural heritage has been for The Church's work, its historic evolution and legislative development both regarding ecclesial and civil issues. The current society has been producing different legal-civil frameworks for the heritage protection. These tools should be used by The Church according to the call made by the Roman Pontiffs in the recent years. Therefore, this paper seek to let known some legislative tools concerning both the civil and the canonic law to allow a better efficiency in the protection of this heritage, focused mainly in the Colombian case.

Keywords: cultural properties, ecclesial properties, Colombia, legal protection.

El hombre, como ser inteligente y libre, sujeto de derechos y obligaciones es el primer principio, es decir, el corazón y el alma de la enseñanza social de la Iglesia, de tal forma que todos los bienes de la tierra deben ordenarse en función del ser humano, centro y cima de todos ellos. La cultura es una parte inherente, en ella el hombre se desarrolla y dignifica, y encuentra su realidad como hijo de Dios; es en el cotidiano de su realidad y en su entorno que este construye.

Dentro de este desarrollo cultural, han existido un grupo de bienes que, siendo de creación del hombre, se destacan por representar sus cualidades espirituales y corporales, su vida y contexto social, su forma de pensar, de sentir y de interpretar su realidad cosmogónica, comunicando a través del tiempo sus experiencias y aspiraciones.

Estos bienes, denominados culturales, por ser obra de la creación humana bajo la inspiración de Dios, al ser testimonio material de la civilización, poseen un valor arqueológico, histórico, artístico, científico o técnico. La Iglesia ha sido parcialmente procuradora de ellos, con respecto a aquellos bienes que a lo largo de su historia han hecho parte de su actividad predicadora.

Actualmente existe un evidente desconocimiento a nivel general sobre la protección, destinación y cuidado del patrimonio cultural de la Iglesia, aunque este se encuentra claramente ligado con su historia e identidad.

Notas de autor

a Autora de correspondencia. Correo electrónico: sandralidiaflorez@yahoo.es 
Tristemente, debido a la enorme cantidad de recursos que se requiere para su mantenimiento y conservación, algunos de estos bienes se encuentran en grave deterioro y amenaza de pérdida, por lo cual se ha hecho necesario adelantar convenios con los gobiernos de los diferentes países a fin de que, de manera conjunta, se preserven y protejan.

En este artículo, comenzaremos con un análisis que, partiendo de la Sagrada Escritura, muestre someramente la evolución de estos bienes y su importancia en la historia de la Iglesia, junto con su visión actual, en especial el Código de Derecho Canónico (CIC).

\section{Análisis desde la Sagrada Escritura}

Es innegable que gran parte de la historia del arte, tanto en Occidente como en Oriente, tiene que ver con la historia de la Iglesia, y el desarrollo de la iconografía y del arte ha dependido de las diversas orientaciones y movimientos que esta ha tenido. Por ello, en los bienes o patrimonio cultural no se puede dejar de lado el tema de lo sagrado y el significado que las imágenes han querido presentar, razón por la cual partiremos de plantear que la semiótica es una pequeña muestra de estos desde el Antiguo y el Nuevo Testamento y la evolución que ha tenido a lo largo de la historia de la Iglesia.

La semiótica es un sistema que abarca los signos de comunicación. Ella es en sí la teoría de los signos, que aborda la interpretación y producción de sentido que se genera a partir del signo; se conoce también como la disciplina encargada del estudio del signo, es decir, de aquello que se emplea para representar una idea o un

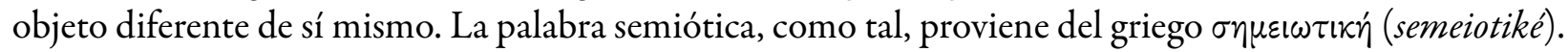

Toda imagen o elemento puesto como signo está compuesto de la siguiente manera:

- $\quad$ Signo = significante (medio)

- Significado (lo que se busca comunicar)

Por ende, para que un signo sea eficaz, el receptor debe conocer su significado. Lo anterior es importante en relación con el tema que nos ocupa, ya que desde los inicios de la historia de salvación, Dios ha querido revelarse, manifestarse como muestra de su bondad.

Con Adán y Eva, la manifestación era directa, pero el pecado rompió esta relación (Génesis 3:8). Desde entonces, Dios siempre ha buscado comunicarse, para ello emplea a personas, como Noé (Génesis 6) y Abraham (Génesis 17), y signos diversos, como con Moisés y la zarza (Éxodo 3), el trueno y la columna de nube (Éxodo 33:9), y Elías y la suave brisa (1 Reyes 19:12). A través de esta manifestación de Dios a los hombres, también algunos objetos han adquirido un carácter sacro, de modo que los signos y objetos se cargan de un valor de culto que enriquece su valor cultural, artístico, histórico y documental, como los que se señalan a continuación.

\section{La creación de altares}

Génesis 8:20-22: "Noé construyó un altar a Yavé".

Génesis 12:7-8: "Abram edificó un altar a Yavé, que se le había aparecido [...]. También aquí edificó un altar a Yavé e invocó su Nombre".

Deuteronómio 27:5-7: "Levántarás allí en honor de Yavé un altar de piedras”. 


\section{Elementos litúrgicos}

Éxodo 29:4-7: "Luego revestirás a Aarón de sus ornamentos, esto es, de la túnica de lino, el manto del Efod, el Efod, y el Pectoral, que ceñirás con el cinturón del Efod”.

Éxodo 29:29-30: "Las ropas santas de Aarón pasarán a sus hijos después de su muerte".

Éxodo 30:26- 28: "Con él ungirás la Tienda de las Citas y el Arca del Testimonio, la mesa con todos sus vasos, el candelabro con todos sus utensilios, el altar del incienso, el altar de los holocaustos con todos sus utensilios y la pila con su base".

El patrimonio como herencia trasmite la unidad e identidad de un grupo, por eso no solo los objetos y los lugares sagrados son importantes, sino que también, partiendo de la premisa anterior, se entiende que la liturgia constituye parte de ese patrimonio inmaterial con el que se mantiene y ratifica la común-unión.

\section{Las fiestas y procesiones (patrimonio inmaterial)}

Deuteronómio 16:15-17: “Celebrarás también la fiesta de las Tiendas durante siete días, después de recoger el producto de tu era y de tu lagar".

Salmos 1 18:25-29: "Formen la procesión con ramos en la mano hasta los cuernos del altar. Tú eres mi Dios, te doy gracias; ¡Dios mío, te digo que eres grande! Den gracias al Señor, pues él es bueno, pues su bondad perdura para siempre".

Estas citas del Antiguo Testamento nos revelan cómo entre los bienes temporales hay unos que, dado su significado en la relación del hombre con Dios, eran tratados y cuidados de forma diferente, lo que muestra que nosotros no debemos perder esta tradición antigua, sino buscar su protección y cuidado.

El Evangelio, por su parte, prohíbe a los que desean alcanzar la perfección amontonar tesoros y conservar los bienes temporales, como terminantemente puede verse en San Mateo 6:19-21:

No os amontonéis tesoros en la tierra, donde hay polilla y herrumbre que corroen, y ladrones que socavan y roban. Amontonaos más bien tesoros en el cielo, donde no hay polilla ni herrumbre que corroan, ni ladrones que socaven y roben. Porque donde esté tu tesoro, allí estará también tu corazón.

Sin embargo, San Pablo en diversas cartas nos habla de la importancia de la tradición: "Así pues hermanos manteneos firmes y conservad las Tradiciones que habéis recibido de nosotros" (2 Tesalonicenses 2:15). Esta cita es el sustento de la tradición en la Iglesia, el patrimonio cultural inmaterial que siempre nos ha acompañado. En otros textos San Pablo afirma: "Aunque espero ir a verte pronto, te escribo estas cosas por si me atraso. Así sabrás cómo comportarte en la casa de Dios, es decir, en la Iglesia del Dios viviente, columna y fundamento de la verdad" (1 Timoteo 3:14-15).

\section{Importancia en la historia de la Iglesia}

Los apóstoles y sus primeros sucesores no podían recibir bienes inmuebles, solo aceptaban su valor y, después de gastar lo necesario para su subsistencia, distribuían lo restante entre los pobres. Tal como lo relata Hechos 5:1-11.

Sin embargo, una muestra de la relevancia del patrimonio cultural para el pueblo cristiano desde la antiguedad se puede ver en las pinturas de las catacumbas.

En la época del papa Gregorio Magno (590-604), se llevará a cabo una primera intervención por parte del magisterio papal sobre el reconocimiento del valor del arte sacro. Según está escrito en el Liber Pontificalis (Maymó i Capdevila, 2013), el papa pide el uso de las imágenes, en cuanto son útiles para fijar la memoria de la fe cristiana, por ser un instrumento por medio del cual se puede enseñar la fe. Estos escritos recopilados en 
el Liber Pontificalis y los Inventari documentan la atención puesta por los papas en el arreglo y ornamentación de las Iglesias y los objetos de culto.

También los concilios ecuménicos se ocuparon de la tutela de los bienes culturales. Al respecto, podemos recordar el IV Concilio de Constantinopla (869-870 d. de C.) y el I Concilio de Lyon (1274 d. de C), en el que en la tercera y última sesión, del día 17 de julio, se dictaron algunos decretos sobre la conservación de los bienes de la Iglesia.

El II Concilio de Nicea (787 d. de C) debatió el tema de las imágenes. La decisión final de este concilio apoya el uso de imágenes, con lo que se da fin a la lucha iconoclasta.

La Iglesia monástica tiene un papel preponderante en el desarrollo de la Iglesia y de las artes. La abadía de Cluny, fundada en el año 910, no solo la vida reaviva en la Iglesia, sino que extiende el arte romántico, que es también un mecanismo de conservación de los textos antiguos de la literatura clásica.

Otro factor de vital importancia durante la Edad Media es la aparición de las conocidas órdenes mendicantes (dominicos y franciscanos), quienes han cultivado una gran atención hacia los bienes artísticos, hasta el punto de crear un estilo propio.

En la Era Moderna, desde finales del siglo XIX y durante el siglo XX, el patrimonio cultural ha sido un constante motivo de estudio del patrimonio cultural y su respectiva protección y vigilancia, hecho que ha suscitado la publicación de diversos documentos eclesiales, como la circular del 1 de septiembre de 1924 de la Secretaría de Estado a los Ordinarios de Italia (por la que se constituye la Comisión Pontificia Central para el Arte Sagrado en Italia), las disposiciones de la Sacra Congregazione per il Concilio para la conservación del patrimonio en Italia dadas el 24 de mayo de 1939 o la creación en el año 1903 de la institución de la figura del comisariato para la protección de los bienes, entre otros, como los escritos de San Pío X del 22 de noviembre de 1903, y, en tiempos más actuales, lo manifestado por Pío XII con respecto a la idoneidad de las obras que debían adornar las iglesias, inculcada en la encíclica Mediator Dei (1947).

Consecuentemente, también el CIC de 1917 trata la materia de los bienes temporales en la parte sexta del canon 1491, y en especial da la misión a los administradores de los bienes eclesiásticos de realizar un inventario (c. 1522), el cual debía especificar los cambios que tuviera este patrimonio.

Posterior al CIC de 1917, son de vital importancia las circulares del secretario de Estado, cardenal Gasparri, principalmente la Carta circular a los Ordinarios de Italia sobre la conservación, la tutela y el uso de los archivos y de las bibliotecas eclesiásticas, del 15 de abril de 1923, en la que se busca crear una "Comisión Central especial para el Arte Sacro en toda Italia”, que proteja o promueva el patrimonio cultural en la Iglesia italiana (Secretaría de Estado, 1 de septiembre de 1924, pp. 196-198).

\section{El patrimonio cultural de la Iglesia desde el Concilio Vaticano II}

El Concilio Vaticano II da un nuevo impulso a la visión de la Iglesia en lo concerniente al patrimonio cultural. Muestra de ello es la definición de cultura que da la Constitución pastoral Gaudium et Spes (1965), en su numeral 53, que cita:

Con la palabra cultura se indica, en sentido general, todo aquello con lo que el hombre afina y desarrolla sus innumerables cualidades espirituales y corporales; procura someter el mismo orbe terrestre con su conocimiento y trabajo; hace más humana la vida social, tanto en la familia como en toda la sociedad civil, mediante el progreso de las costumbres e instituciones; finalmente, a través del tiempo expresa, comunica y conserva en sus obras grandes experiencias espirituales y aspiraciones para que sirvan de provecho a muchos, e incluso a todo el género humano.

Esta definición marca la importancia, en el mundo moderno, de la protección del patrimonio como muestra del desarrollo de sus cualidades, del caminar en el devenir histórico, de cómo Dios ha ido revelando su misterio de salvación al hombre en su propio entorno, en su propia época; el cual es necesario mantener y proteger, dando acceso a todos los hombres. La Congregación para el Clero, con carta circular del 11 de abril de 1971, 
conocida como la carta Opera Artis, prescribía el inventario para los edificios sagrados y los objetos de valor artístico o histórico, siendo el primer documento de la Santa Sede específico sobre el tema.

\section{Análisis desde el CIC de 1983 hasta la actualidad}

Los bienes temporales, entendidos como “aquellos que sirven para la vida temporal”, y más específicamente en relación con el tema a tratar, pueden ser distinguidos de los bienes eclesiásticos: "Todos los bienes temporales que pertenecen a la Iglesia universal, a la Sede Apostólica o a otras personas jurídicas públicas en la Iglesia" (CIC, c. 1257, § 1).

De igual manera, es conveniente aclarar que se denominan como cosas sagradas aquellos bienes destinados al culto divino mediante dedicación o bendición. También está la noción de cosa preciosa, entendida como el bien temporal eclesiástico cuya preciosidad le viene por motivos derivados del arte o de la historia de cada pieza.

De igual forma, el CIC de 1983, si bien no presenta un tratamiento sistemático sobre los bienes culturales, en el libro quinto, que regula lo concerniente a los bienes temporales de la Iglesia, encontramos la normatividad que se le puede adaptar a este tipo de bienes, junto con otros cánones de otros libros que también les son aplicables; de esta forma observamos cómo a partir del canon 1254 — que reza: "Por derecho nativo, e independiente de la potestad civil, la Iglesia Católica puede adquirir, retener, administrar y enajenar bienes temporales para alcanzar sus propios fines"- se encuentra el fundamento primario para la adquisición y administración de los bienes culturales por parte de la Iglesia.

Por su parte, el canon 1216, en materia de promoción del arte y la conservación de sus obras con referencia a los templos, dispone que "en la construcción o restauración de las Iglesias, con el consejo de peritos, obsérvense los principios y normas de la liturgia y el arte sagrado".

Las imágenes preciosas, o sea, sobresalientes por su antigüedad, arte o culto, que estén expuestas en iglesias u oratorios para la veneración de los fieles, cuando necesiten reparación, nunca se deben restaurar sin la licencia del Ordinario, dada por escrito, quien, antes de concederla, debe consultar a los peritos.

Se establece en el canon 1284, parágrafo 2, de forma similar, la obligación de los administradores de

vigilar para que los bienes confiados a su cuidado de ningún modo perezcan o sufran algún daño o detrimento, tomando, para este fin, en cuanto sea necesario, las pólizas de seguros y que: Antes que los administradores inicien su cargo. 2. elabórese un cuidadoso y detallado inventario de los inmuebles, de los muebles preciosos o cualquier otro bien perteneciente a los bienes culturales y a los otros, con la descripción y el valor de los mismos, y una vez redactado se reconozca; 3 . De este inventario, un ejemplar se conserve en el archivo de la administración, otro en el archivo de la curia, y en ambos se anote cualquier cambio, que pueda sufrir el patrimonio.

A su vez, el canon 1234, en el numeral 2, señala: "Los exvotos [ofrendas a la Virgen y a los santos por milagros o beneficios concedidos] de los santuarios y lugares adyacentes sean puestos a la vista de los fieles con las debidas medidas de seguridad".

Es de destacar, por su parte, que la normatividad canónica sostiene el principio general de que para poder enajenar cualquier bien temporal de la Iglesia es necesario obtener la licencia de la autoridad eclesiástica, y para el evento de los bienes considerados como preciosos el procedimiento para su transmisión a cualquier título requiere autorización de la misma Sede Apostólica, como reza el canon 1292, numeral 2:

Sin embargo, si se trata de cosas cuyo valor exceda la cantidad máxima, o de cosas donadas a la Iglesia como exvoto, o de cosas preciosas a causa del arte o de la historia, para la validez de la alienación se requiere además la licencia de la Santa Sede.

En el mismo sentido se pronuncia el canon 1190 para el caso de reliquias insignes o muy veneradas, prohibiendo la enajenación de las reliquias consideradas sagradas. 
En el canon 1171, se establece la obligación de tratar con reverencia a estos bienes y la prohibición de emplearlos para un uso profano o impropio, así su titularidad pertenezca a particulares, teniendo presente que el término dedicación se asemeja a consagración, por ello las cosas sagradas tienen una especial dignidad, que exige un trato reverente sustrayéndolo de usos profanos.

La Santa Sede, preocupada ante todas las eventualidades que pueden llegar a afectar los bienes temporales asignados, ha creado una comisión encargada de este tema, y ha logrado ordenar, haciendo ingentes esfuerzos para que no se sigan perdiendo debido al desconocimiento, la ligereza o la falta de proyectos claros, que se detengan las fallas que hasta el presente se han venido presentando.

Por su parte, con el motu proprio Inde a Pontificatus Nostri Initio, de Juan Pablo II, nació en 1993 la Pontificia Comisión para los Bienes Culturales de la Iglesia, en sustitución de la Pontificia Comisión para la Conservación del Patrimonio Artístico de la Iglesia, creada cinco años antes mediante la Constitución apostólica Pastor Bonus, en el ámbito de la Congregación para el Clero (Pontificia Comisión para los Bienes Culturales de la Iglesia, 2017), cuyos artículos 100, 101, 103 y 104 establecían las funciones propias de esta comisión:

Artículo 100. A este patrimonio pertenecen, en primer lugar. todas las obras de cualquier arte del pasado, arre es necesario custodiar y conservar con la máxima diligencia. Y aquellas que no tengan ya un uso específico, se guardarán convenientemente para su exposición en los museos de la Iglesia o en otros lugares.

Artículo $101 \S 1$. Entre los bienes históricos, tienen particular importancia todos los documentos e instrumentos que se refieren y atestiguan la vida y la acción pastoral. así como los derechos y las obligaciones de las diócesis, parroquias, iglesias y demás personas jurídicas instituidas en la iglesia. [...]

Artículo 103. Corresponde a la Comisión, consultando a las Congregaciones de los Seminarios e Instituciones de Estudios, del Culto Divino y de la Disciplina de los Sacramentos, trabajar para que el Pueblo de Dios sea cada vez más consciente de la importancia y necesidad de conservar el patrimonio histórico y artístico de la Iglesia.

$\$ 2$. Este patrimonio histórico consérvese en los archivos o también en las bibliotecas, que en todas partes han de encomendarse a personas competentes, para que dichos testimonios no se pierdan. (Juan Pablo II, 1988)

Uno de los documentos que nos pueden mostrar la importancia de este patrimonio cultural, puesto que es muestra de la riqueza de la historia del cristianismo sin dejar de lado su valor, es la carta emitida por la Pontificia Comisión para los Bienes Culturales de la Iglesia el 8 de diciembre de 1999, en la que se habla sobre la necesidad y urgencia de inventariar y catalogar los bienes culturales de la Iglesia. En ella se afirma:

El impacto del patrimonio histórico-artístico de la Iglesia en su conjunto del patrimonio cultural de la humanidad es enorme, tanto por la cantidad y variedad de productos, tanto por la calidad y la belleza de muchos de ellos. Ni siquiera se puede hablar de las personalidades eminentes que han puesto su talento al servicio de la Iglesia. Toda vocación artística, de hecho, da testimonio del mensaje cristiano a todos los pueblos. Todas las obras de arte inspiradas en los valores cristianos son una expresión de la espiritualidad universal y local. Se puede coincidir con la búsqueda religiosa individuo y la comunidad, llegando, en algunos casos, las formas de armonía total entre el fruto creativo y espiritual. (Pontificia Commissione per i Beni Culturali della Chiesa, 8 de diciembre de 1999)

La función ininterrumpida cultural y eclesial que produce esos bienes es el mejor apoyo para su conservación. Se debe pensar en lo difícil y costoso que para la comunidad se convierte el mantenimiento de las estructuras que han perdido su destino original y cuán complejas son las opciones para identificar otras nuevas. Además de la "protección de la vida" del patrimonio cultural, es importante su "contexto de conservación", ya que el desarrollo debe entenderse como un todo, especialmente con respecto a los edificios sagrados, donde se encuentra la mayor parte del patrimonio histórico-artístico de la Iglesia" (Pontificia Commissione per i Beni Culturali della Chiesa, 8 de diciembre de 1999).

El 30 de julio de 2012, el papa Benedicto XVI, con el motu proprio Pulchritudinis Fidei, agregó al Consejo la Comisión Pontificia para los Bienes Culturales de la Iglesia.

En este documento se establece:

La Iglesia, testigo de la belleza de la fe y depositaria de la verdad del Evangelio, siempre ha manifestado su gran interés por el mundo de la cultura y de las artes. En este ámbito particular, ella realiza la propia misión ofreciendo a la cultura y al genio 
humano la luz fecunda del Evangelio de Cristo, por medio del diálogo y la recíproca interacción. (Benedicto XVI, 30 de julio de 2012)

Con esto retoma lo dicho en el discurso al Consejo Pontificio para la Cultura, del 15 junio de 2007, en el que el papa Benedicto XVI nos recuerda que "la historia de la Iglesia es también inseparablemente historia de la cultura y del arte", así como también que aparece claro que "hoy, más que nunca, la apertura recíproca entre las culturas es un terreno privilegiado para el diálogo entre hombres comprometidos en la búsqueda de un humanismo auténtico, por encima de las divergencias que los separan" (Benedicto XVI, 15 de junio de 2007).

Con lo enumerado anteriormente, queda en evidencia el interés que a lo largo de la historia ha tenido la Iglesia en la protección de su patrimonio cultural. Sin embargo, es necesario aclarar que esta protección no se ha limitado exclusivamente al campo jurídico, como ya lo habíamos mencionado, sino que una de las formas para concretar esta protección es a través del inventario y catalogación de los bienes culturales de la Iglesia, labor que responde a la necesidad de conocer con anterioridad de qué manera está formado este patrimonio. Este trabajo de inventariar todos los objetos religiosos, en primer lugar, utilizando registros sistemáticos por medios escritos y, más recientemente, registros informáticos y su posterior catalogación, fase en la cual el objeto así registrado se clasifica, considerando su contexto, significado y valoración, han permitido implementar tareas conducentes no solo a la conservación de los bienes culturales, sino a su recuperación y mejor aprovechamiento.

Lo anterior se lleva a cabo cumpliendo lo que expresa el canon 1283 sobre el deber de los administradores, cuyo numeral 2 dice:

Hágase inventario exacto y detallado, suscrito por ellos, de los bienes inmuebles, de los bienes muebles tanto preciosos como pertenecientes de algún modo al patrimonio cultural, y de cualesquiera otros, con la descripción y tasación de los mismos; y compruébese una vez hecho.

\section{Normativa internacional para la protección del patrimonio cultural de la Iglesia}

En el contexto mundial, sin lugar a dudas, la entidad que más ha promovido y difundido la protección del patrimonio cultural es la Organización de las Naciones Unidas para la Educación, la Ciencia y la Cultura (Unesco), la cual, como su nombre lo dice, es una organización especializada de las Naciones Unidas para la educación, la ciencia y la cultura, que tiene como objetivo primordial la construcción de la paz en la mente de los hombres, mediante la educación, la cultura, las ciencias naturales y sociales y la comunicación.

A nivel internacional, existen una serie de convenciones y acuerdos que han buscado proteger este patrimonio. La importancia de estas convenciones se encuentra, como nos lo ilustra el profesor Marco Gerardo Monroy Cabra (1986), en que "debe tenerse presente que en la actual evolución del derecho internacional hay una serie de fuentes políticas que poseen fuerza jurídica. Estas son principalmente las recomendaciones internacionales, y las resoluciones y declaraciones de la ONU sobre algunas cuestiones importantes" (p. 35).

La implementación de estas políticas en la actualidad hacen parte de todo un sistema jurídico internacional en su sentido más amplio. Entre los instrumentos jurídicos internacionales administrados por la Unesco, tenemos:

1. Recomendación relativa a la protección y promoción de los museos y colecciones, su diversidad y su función en la sociedad ( 17 de noviembre de 2015)

2. Recomendación sobre el paisaje urbano histórico, con inclusión de un glosario de definiciones (10 de noviembre de 2011) 
3. Convención sobre la protección y la promoción de la diversidad de las expresiones culturales (París, 20 de octubre de 2005, ratificado el 19 de marzo de 2013)

4. Convención para la salvaguardia del patrimonio cultural inmaterial (París, 17 de octubre de 2003. Ratificado el 19 de marzo de 2008, y vigente desde el 19 de junio de 2008)

5. Declaración de la Unesco relativa a la destrucción intencional del patrimonio cultural (17 de octubre de 2003. Ratificado el 19 de marzo de 2008, y vigente desde el 19 de junio de 2008)

6. Declaración Universal de la Unesco sobre la Diversidad Cultural (2 de noviembre de 2001. En trámite)

7. Recomendación sobre la Protección de los Bienes Culturales Muebles (28 de noviembre de 1978)

8. Recomendación sobre el Intercambio Internacional de Bienes Culturales ( 26 de noviembre de 1976)

9. Convención sobre las Medidas que Deben Adoptarse para Prohibir e Impedir la Importación, la Exportación y la Transferencia de Propiedad Ilícitas de Bienes Culturales (París, 14 de noviembre de 1970. Aceptado el 24 de mayo de 1988, y vigente desde el 24 de agosto de 1988)

10. Convención del Patrimonio Mundial de 1972 (aceptada el 24 de mayo de 1983, y vigente desde el 24 de agosto de 1983)

11. Recomendación sobre la Conservación de los Bienes Culturales que la Ejecución de Obras Públicas o Privadas Pueda Poner en Peligro (19 de noviembre de 1968)

12. Declaración de los Principios de la Cooperación Cultural Internacional (4 de noviembre de 1966)

13. Recomendación sobre las Medidas Encaminadas a Prohibir e Impedir la Exportación, Importación y Transferencia de Propiedad Ilícitas de Bienes Culturales (19 de noviembre de 1964)

14. Convención para la Protección de los Bienes Culturales en Caso de Conflicto Armado y Reglamento para la Aplicación de la Convención de La Haya del 14 de mayo de 1954 (ratificado mediante Ley 1130 de 2007)

Las anteriores normas, dependiendo su naturaleza jurídica, tienen una mayor o menor jerarquía legal, en la que las convenciones y sus protocolos constituyen verdaderos acuerdos internacionales que, según la doctrina, se clasifican como tratados internacionales abiertos, multilaterales y generales, en virtud de que permiten la adhesión de otros Estados, son celebrados entre dos o más sujetos de derecho internacional y por su vocación tienden a la universalidad en su aplicación, hecho de vital importancia. Por otra parte, se encuentran las declaraciones y recomendaciones, las cuales proporcionan directrices de conducta que no son en sentido estricto normas vinculantes. Las declaraciones reflejan principios que los Estados acuerdan en el momento de su aprobación y proclaman estándares que imponen obligaciones morales de gran trascendencia para los Estados miembros. Las recomendaciones contienen sugerencias de órganos internacionales con el fin de influir en el desarrollo legislativo de los Estados. Si bien es cierto que tanto las declaraciones como las recomendaciones no precisan ser ratificados, sí es costumbre tenerlas en cuenta, si pretendemos que el patrimonio cultural de la Iglesia en Colombia sea eficazmente protegido.

\section{Evolución legislativa en Colombia en materia civil para la protección del patrimonio cultural religioso}

Colombia acoge estas nuevas corrientes internacionales que buscan proteger el patrimonio cultural, muestra de ello son las diversas convenciones internacionales ratificadas por nuestro país que manifiestan su interés en proteger esta parte cultural, esencial en el desarrollo de cualquier pueblo. A continuación, vamos a revisar y analizar someramente la legislación que actualmente da a la Iglesia católica herramientas que permitan la protección de este patrimonio, sin perder la titularidad de los bienes. Para ello, partiremos de un análisis de 
la realidad de la Iglesia en nuestro país, su relación con el Estado colombiano y la evolución legislativa que ha tenido la protección del patrimonio, con el fin de tener una mejor visión del caso colombiano.

La República de Colombia en la actualidad posee una Constitución vigente, que data del 5 de julio de 1991, la cual contempla un sistema democrático participativo que tiene en cuenta la tradición del país. Por lo tanto, aunque en materia religiosa legislativa se considere un país no confesional de tipo laicista, no puede dejar de lado la importancia que tiene la religión dentro de su población y en el desarrollo histórico y social, puesto que la cantidad de población bautizada (45,3 millones de personas, según el Annuarium Statisticum Ecclesiae del año 2017 [Secretaría de Estado, 2017]) manifiesta la importancia de la presencia de la Iglesia católica en la vida del país; elemento importante para nuestro estudio. Estas dos posturas manifiestan la realidad de Colombia, en donde, si bien su legislación es de tipo laicista, en su población e historia es de vital importancia el hecho religioso católico. Por este motivo, teniendo en cuenta la tradición, con la Iglesia católica se suscribió un concordato, ratificado mediante la Ley 20 de 1974, el cual fue declarado inconstitucional en algunas de sus partes mediante sentencia C027/93, que en materia de bienes no sufrió ningún detrimento que sea tema de interés de nuestro estudio. Este concordato (Concordato entre la Repu\#blica de Colombia y la Santa Sede, 1973), en su artículo XXIII, establece:

La Iglesia Católica y las demás personas jurídicas de que trata el artículo IV del presente Concordato tiene facultad de adquirir, poseer, enajenar, y administrar libremente bienes muebles e inmuebles en la forma establecida por la legislación colombiana para todos los ciudadanos, y sus propiedades, funciones y derechos serán no menos inviolables que los pertenecientes a las demás personas naturales y jurídicas.

Y en su artículo XXVIII dice:

En defensa y promoción del patrimonio cultural colombiano la Iglesia y el Estado colaborarán en el inventario del arte religioso nacional, que incluirá monumentos, objetos de culto, archivos, bibliotecas y otros que por su valor histórico o estético sean dignos de conjunta atención para conservarse, restaurarse y exponerse con fines de educación social.

Estos elementos introducidos en el concordato entre Colombia y la Santa Sede manifiestan de modo claro el compromiso que se da entre el Estado y la Iglesia para proteger los bienes de interés cultural, sin que esto obstruya la titularidad de la Iglesia y el derecho que tiene para protegerlos, contando con la colaboración activa del Estado colombiano. No debemos dejar de lado este elemento, si queremos que lo que se ha planteado en las diferentes normas tanto internacionales como nacionales sea cumplido, para poder preservar los bienes, en especial los referidos al patrimonio cultural de la Iglesia, sin desconocer el fin para el cual han sido creados.

El Decreto 782 de 1995, que reglamenta la Ley 133 de 1994, sobre libertad religiosa, teniendo en cuenta lo establecido anteriormente mediante el Concordato y en razón de las sentencias del tribunal constitucional colombiano sobre este, tuvo que ser modificado por el Decreto 1396 de 1997.

Encontramos en el artículo 14 del referido decreto que solamente estarán capacitados para celebrar convenios de derecho público interno las entidades religiosas con personería jurídica especial o de derecho público eclesiástico, entidades que son reconocidas por el Estado colombiano en virtud del Concordato, estableciendo la salvedad de que la celebración de convenios de derecho público interno con las personas jurídicas de derecho público eclesiástico se hará siempre por intermedio de la Conferencia Episcopal de Colombia (CEC).

De esta forma se explica el fundamento jurídico del convenio celebrado entre el Estado colombiano y la Iglesia católica, el cual, donde se constituye un marco jurídico y es base para la celebración de otros convenios específicos para la protección de bienes culturales de la Iglesia entre personas de derecho público eclesiástico y entidades públicas del orden nacional, departamental o municipal, según el caso, sirve de fuente primigenia para un adecuado amparo jurídico de los bienes culturales por proteger, sin que este tipo de acuerdos puedan desconocer las normas de orden público referidas anteriormente sobre el manejo de los bienes de interés cultural. 
La carta política, al reconocer que la cultura en sus diversas manifestaciones es fundamento de la nacionalidad (art. 72), cambió diametralmente el concepto que se tenía de cultura, como un tema accesorio y ornamental de la sociedad, como un divertimento elitista. Ahora la cultura bajó de la superficie para ser reconocida como su raíz, como la base o razón de ser de la nación colombiana, nación múltiple y diversa.

La promoción y el fomento de la cultura en general es una de las preocupaciones consagradas por el constituyente en la carta política, destacando la importancia que para la identidad nacional tiene este aspecto.

Art. 70. El Estado tiene el deber de promover y fomentar el acceso a la cultura de todos los colombianos en igualdad de oportunidades, por medio de la educación permanente y la enseñanza científica, técnica, artística y profesional en todas las etapas del proceso de creación de la identidad nacional.

La cultura en sus diversas manifestaciones es fundamento de la nacionalidad. El Estado reconoce la igualdad y dignidad de todas las que conviven en el país. El Estado promoverá la investigación, la ciencia, el desarrollo y la difusión de los valores culturales de la nación.

Art. 71. La búsqueda del conocimiento y la expresión artísticas son libres. Los planes de desarrollo económico y social incluirán el fomento a las ciencias y, en general, a la cultura. El Estado creará incentivos para personas e instituciones que desarrollen y fomenten la ciencia y la tecnológica y las demás manifestaciones culturales y ofrecerá estímulos especiales a personas e instituciones que ejerzan estas actividades." (Constitución Política de Colombia, 1991)

El artículo 72 de la Constitución colombiana, a su vez, es la norma más importante que con relación a la protección del patrimonio cultural de la nación existe en toda la carta política.

Art. 72. El patrimonio cultural de la nación está bajo la protección del Estado. El patrimonio arqueológico y otros bienes culturales que conforman la identidad nacional, pertenecen a la nación y son inalienables, inembargables e imprescriptibles. La ley establecerá los mecanismos para readquirirlos cuando se encuentren en manos de particulares y reglamentará los derechos especiales que pudieran tener los grupos étnicos asentados en territorios de riqueza arqueológica. (Constitución Política de Colombia, 1991)

A través de este artículo, se contempla el imperativo categórico de la protección de los bienes culturales que hagan parte de la identidad nacional en cabeza del Estado, aspecto principal para la protección de los bienes culturales de la Iglesia, dado que el carácter católico del pueblo colombiano determina que las más de las veces estos bienes hagan parte de la propia identidad nacional de todos los colombianos.

\section{Estructura administrativa y normas legales aplicables para la protección de los bienes culturales de la Iglesia en la República de Colombia}

La entidad gubernamental que por excelencia tiene la función de promover y fomentar la cultura en el país y proteger el patrimonio histórico y cultural de la nación es el Ministerio de Cultura, entidad creada a través de la Ley 397 de 1997, reestructurada por el Decreto 1126 de 1999 y modificada por la Ley 1185 de 2008. Este ministerio pertenece a la rama ejecutiva de los poderes públicos y al sector central de la administración como organismo principal, y dentro de la rama administrativa ostenta una jerarquía muy alta. No se debe olvidar, claro está, que dentro de la institucionalidad colombiana existen otras entidades que se han destacado por su colaboración en la protección del patrimonio cultural, tales como el Banco de la República o el Instituto Colombiano de Cultura Hispánica, por mencionar tan solo las que tienen vínculo con el sector público de Colombia.

Dentro del marco legislativo en materia de protección del patrimonio, tenemos las siguientes normas, las cuales analizaremos según el interés del estudio: 


\section{Legislación vigente}

1. La Ley 397 de 1997, Ley General de Cultura, la cual desarrolló en su momento los artículos 70, 71,72 y demás concordantes de la Constitución política y dictó normas sobre patrimonio cultural, fomentos y estímulos a la cultura. Con esta ley se crea el Ministerio de la Cultura y se trasladan algunas dependencias. Fue modificada por la Ley 1185 de 2008.

2. Decreto 763 de 2009. Por el cual se reglamentan parcialmente las Leyes 814 de 2003 y 397 de 1997, modificada por medio de la Ley 1185 de 2008, en lo correspondiente al patrimonio cultural de la nación de naturaleza material. Este decreto establece el procedimiento administrativo para declarar un bien de interés cultural.

3. Decreto 2941 de 2009. Por el cual se reglamentan parcialmente las Leyes 814 de 2003 y 397 de 1997 modificada por medio de la Ley 1185 de 2008, en lo correspondiente al patrimonio cultural de la nación de naturaleza inmaterial.

4. Resolución 983 de 2010. Por la cual se desarrollan algunos aspectos técnicos relativos al patrimonio cultural de la nación de naturaleza material. En especial, lo relacionado con los inventarios y su actualización.

La normatividad vigente en el territorio colombiano busca generar políticas que lleven a la protección del patrimonio cultural en un conjunto de estrategias que se encuentren coordinadas y sean sostenibles a corto, mediano y largo plazo; de acuerdo con todo el componente normativo, se busca que bajo la intervención de diversos agentes, como son las instituciones del campo cultural y de toda la sociedad, en especial de la Iglesia, se pueda fortalecer e incrementar la gestión y mantenimiento de estos bienes.

El vasto desarrollo normativo que se tiene en Colombia recopila y relaciona la importancia de la cultura, la historia y el pueblo entre el patrimonio cultural mueble y la sociedad, dando a conocer diversas categorías del patrimonio, como el patrimonio cultural inmaterial y los bienes culturales, tanto muebles como inmuebles, pues hay que tener en cuenta que un gran número de manifestaciones culturales se apoyan en objetos cuyo origen e historia fortalecen y sostienen la identidad de la nación colombiana, y dentro de ella específicamente su amplio componente religioso, como eje de la evolución de la vida de nuestro país.

\section{Realidad fáctica con respecto al patrimonio cultural de la Iglesia en Colombia}

Podemos decir que Colombia es una de las naciones con legislación y políticas culturales más completas y detalladas. La vasta documentación a nivel legislativo y jurisprudencial nos deja entrever cómo, desde la promulgación de la Constitución de 1991, ha sido una preocupación del Ejecutivo el generar marcos que permitan la protección del patrimonio cultural.

En los Indicadores Unesco de cultura para el desarrollo: resumen analitico de Colombia del año 2010-2014 (Organización de las Naciones Unidas para la Educación, la Ciencia y la Cultura, s. f.), se establece en materia la dimensión del patrimonio, el cual examina el establecimiento, y la aplicación de un marco multidimensional para su salvaguarda. Allí, Colombia registra en tres aspectos distintos una calificación bastante alta en tres ítems diferentes:

Sostenibilidad del patrimonio: 0,86/1 el cual refleja el alto nivel de prioridad que se da a la protección, salvaguarda y promoción de la sostenibilidad del patrimonio por parte de las autoridades públicas de Colombia. El desarrollo normativo, institucional y de gestión en torno al Patrimonio ha sido considerable en los últimos años.

Un resultado de $0,87 / 1$ para los registros e inscripciones, lo cual indica que los esfuerzos hasta la fecha han dado sus frutos en muchos registros e inscripciones nacionales e internacionales de sitios colombianos y elementos del patrimonio tangible e intangible. [Esta calificación se da por el aumento de los bienes que han sido incluidos dentro de la lista de bienes de interés cultural.] 
Colombia tiene un resultado de $0,80 / 1$, para la protección, salvaguarda y gestión del patrimonio, indicando que hay una serie de políticas y medidas bien definidas, pero que aún persisten ciertas lagunas. (pp. 36-37)

Lo anterior podría indicarnos que, en materia de evaluación institucional general, Colombia ha sido uno de los países que ha procurado la protección de su patrimonio; pero nos puede surgir la pregunta de si, dada la realidad fáctica, es esto del todo cierto.

Sin embargo no podemos desconocer que, a pesar de dichas políticas, la realidad se ve menguada por la crisis y conflicto que se cierne sobre el país, lo que dificulta la actuación de estas. Por otra parte, en esta laicidad reinante, se tiende a desconocer que la mayoría del patrimonio cultural de Colombia es de carácter religioso por la influencia de la fe católica en el desarrollo histórico del país, como lo hemos ido planteando.

En un estudio del año 2015 presentado por Roberto Lleras Pérez, titulado "La producción del patrimonio cultural restaurado", se hace un análisis sobre el cuidado y restauración que han tenido los bienes culturales en Colombia, y se manifiesta que, en los últimos 37 años, en el país se ha hecho una gran inversión económica, de cerca de 45 millones de dólares, para la restauración de estos bienes. Con respecto al campo que nos ocupa, los bienes de carácter religioso, Lleras Pérez establece la relación de la tabla 1.

TABLA 1.

Restauración bienes muebles

\begin{tabular}{l|r|l} 
Tipo de bien & Cantidad restaurada & $\begin{array}{l}\text { Porcentaje del } \\
\text { total }\end{array}$ \\
\hline $\begin{array}{l}\text { Iglesias, templos, catedrales, capillas, basilicas y } \\
\text { ermitas }\end{array}$ & 137 & \\
\hline Sedes, palacios arzobispales y casas curales & 4 & \\
\hline $\begin{array}{l}\text { Conventos, monasterios, casas consistoriales y } \\
\text { claustros }\end{array}$ & 16 & \\
\hline Colecciones de arte religioso & 5 & \\
\hline Total inmuebles y muebles de tipo religioso & 162 & $38,3 \%$ \\
\hline
\end{tabular}

Pérez, R., 2020.

Esta tabla manifiesta cómo la mayoría del patrimonio cultural en Colombia es de carácter religioso; la cultura nacional, desde la Colonia, reitera la preponderancia de los bienes religiosos. El periodo de Conquista y Colonización de nuestro pueblo siempre estuvo enmarcado en el criterio de la evangelización, como nos lo relata la doctora Marta Fajardo de Rueda, en su libro El arte colonial neogranadino neograndino a la luz del estudio iconogra\#fico e iconolo\#gico: "Por su parte, la Iglesia entregada a la labor evangelizadora, cumplió una importantísima función frente a los territorios recientemente conquistados. Alrededor de las diversas advocaciones de la Virgen, de la figura de Cristo y de los santos, se conformaron las cofradías" (1999, p. 39). Este elemento no lo podemos desconocer, porque, aunque, como hemos visto, se ha querido desvirtuar lo sacro de este patrimonio, desde su inicio ha estado enmarcado dentro de la catolicidad del pueblo colombiano.

En otra parte del escrito, Lleras Pérez manifiesta:

Es usual que se hagan colectas y donaciones para terminar o reparar un templo, pintar un cuadro sagrado o recuperar una escultura sacra; las cofradías y familias incurren en gastos enormes para conservar pasos de procesiones; la iglesia es el edificio más grande del pueblo y el mejor construido y si hay una catástrofe será el primero en reconstruirse. En este marco lo más natural es que la iglesia sea restaurada y, como lo demuestran los datos, así ocurre. De esa manera queda comprobado que el bien católico es el patrimonio por excelencia. (2015, p. 393)

Es indudable entonces, como se ha estudiado, que Colombia es una nación católica en todos los sentidos y que, según estos estudios, el patrimonio religioso ha sido en parte restaurado. Y es que, en realidad, es mucholo que no se ha restaurado. Por supuesto que la recuperación y preservación es un campo en el que las necesidades siempre van a superar con creces la disponibilidad de recursos de todo tipo. El porcentaje dedicado por los entes gubernamentales es poco, debido a la cantidad de necesidades que en estos tiempos aquejan la realidad del país.

Podemos decir que, como en muchas otras materias, la producción legislativa es más generosa que la realidad fáctica, con lo que se convierte la norma en el deber ser, que poco llega a cumplirse, si se tiene presente, como se ha dicho, que el problema está más bien en la gestión. Faltan los conocimientos para acceder a estos 
recursos y elaborar planes de ejecución, en general, todo lo que se requiere para gastar bien el dinero. Esto lleva a que solo una fracción de los recursos disponibles se ejecuten en tareas de conservación y restauración.

\section{Análisis del listado de bienes culturales en Colombia}

De acuerdo con lo planteado anteriormente, se podría decir que el principal patrimonio de Colombia en materia de bienes culturales es el enmarcado en la identidad religiosa del pueblo; sin embargo, pese a los diferentes convenios que se han suscrito en materia de patrimonio cultural entre la Iglesia y el Estado colombiano, en los últimos años los bienes culturales de carácter religiosos han ido disminuyendo, de modo que han perdido todos los beneficios legales que se ofrecen para ellos.

En el último listado de bienes de interés cultural se encuentra que en todo el territorio nacional existen 1112 bienes que se encuentran protegidos y pueden ser beneficiados por procesos de restauración y conservación. De estos bienes, solo 211 son de carácter eclesiástico, lo que deja ver que solo el $16 \%$ son parte del patrimonio cultural de la Iglesia.

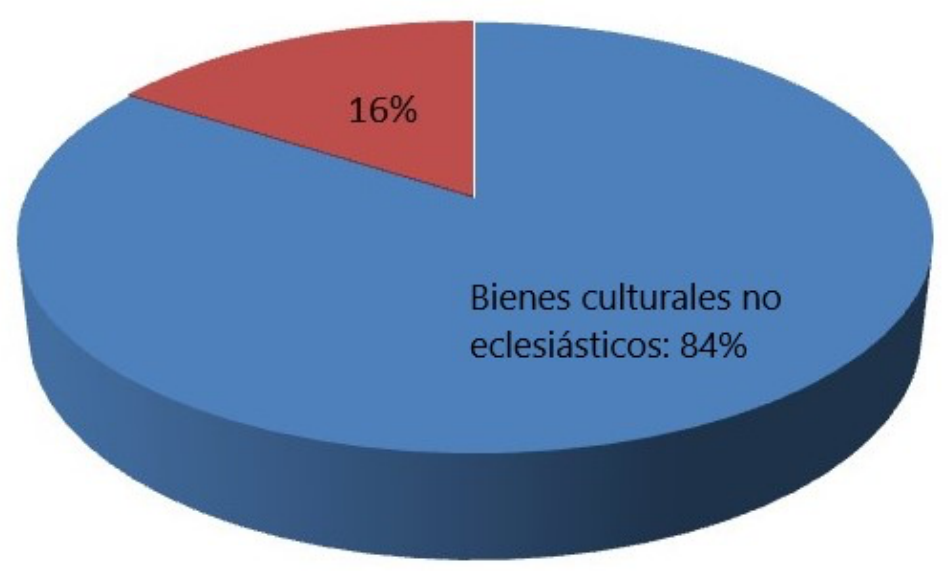

FIGURA 1.

Porcentaje de bienes culturales elaboración propia

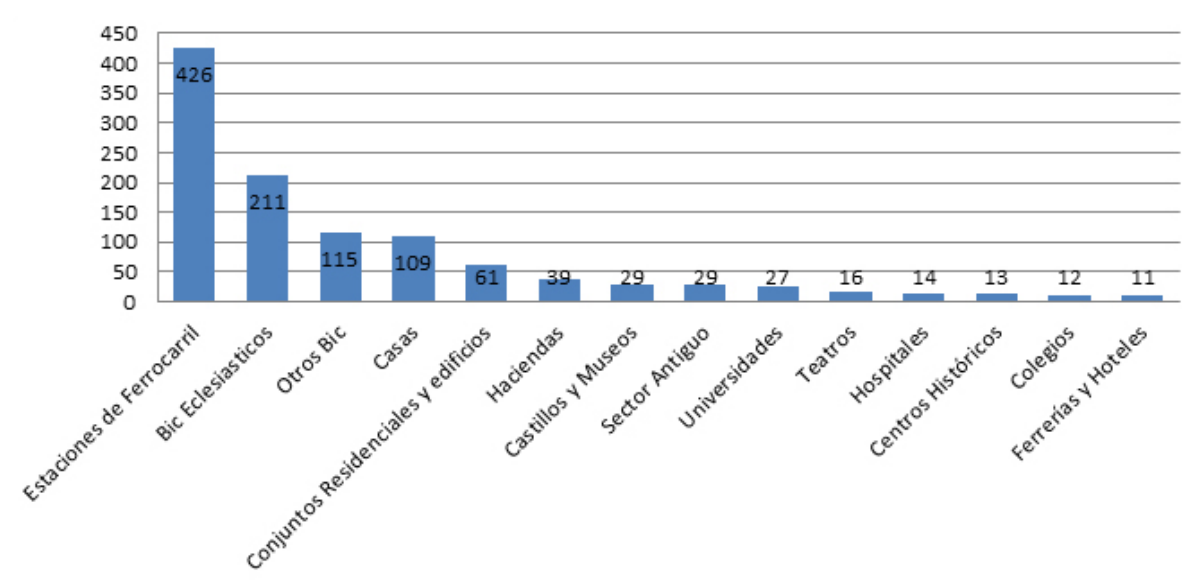

FIGURA 2.

Discriminación de bienes culturales nacionales

elaboración propia 
Las figuras 1 y 2 nos permiten ver cómo ha disminuido la declaración de este patrimonio religioso, lo que es propio del proceso de secularización que se ha ido gestando a través del tiempo. Y cabe por otra parte preguntarnos si no hemos por demás descuidado las gestiones para protegerlos.

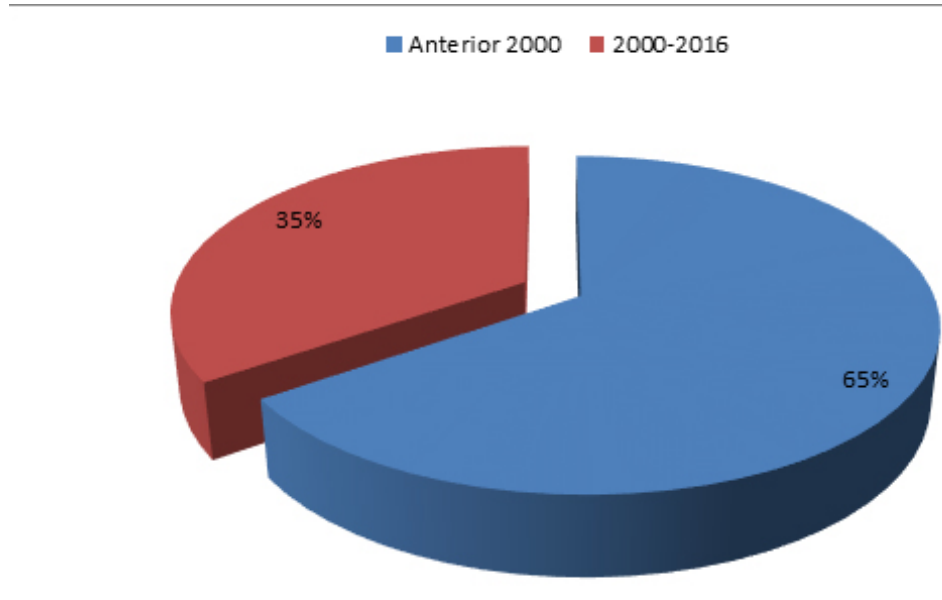

FIGURA 3.

Porcentaje de bienes declarados antes año 2000

elaboración propia

La figura 3 nos muestra cómo ha disminuido considerablemente la inserción de nuevos bienes de interés cultural de carácter nacional con naturaleza religiosa. Esta tendencia nos muestra que no se han tenido en cuenta en esta inclusión puntos importantes, como la no incorporación de todos los archivos eclesiásticos, tales como libros parroquiales, actas, registros y documentos que se encuentran en los diferentes centros de culto, los cuales son una muestra de la evolución y proceso histórico de nuestro país que se encuentra bajo el cuidado de la Iglesia, el cual constituye patrimonio documental.

\section{Análisis de la situación actual de los bienes de interés cultural}

Si bien ya no todo el patrimonio cultural religioso se encuentra bajo la titularidad de la Iglesia, es necesario buscar estrategias para que no pierda la finalidad para la que fue creado, lo que lo llevaría a perder su carácter de sacralidad y a tornarse solo en objeto de arte, o, como lo hemos visto en las nuevas jurisprudencias, a desconocer el valor del patrimonio inmaterial, dejando de lado el arraigo religioso que tiene.

De acuerdo con la normatividad vigente, se podría decir que es más difícil proteger un bien de interés cultural que dejarlo decaer. Esto se ve porque en la realidad no hay un control exhaustivo, y en la actualidad los mayores esfuerzos para la salvaguardia del patrimonio por parte del Gobierno van dirigidos al control del tráfico ilegal de dichos bienes, según lo menciona el citado informe de la Unesco (s. f.).

Amparados en estas normas, en la República de Colombia, entre las autoridades eclesiásticas, representadas por la CEC, y el Estado, representado por el Ministerio de Cultura, se adelantó un convenio de cooperación institucional carente de valor económico, el cual se encuentra vigente desde el año 2010, y se ha ido prorrogando, de modo que estuvo en vigor hasta el 5 de diciembre de 2018, cuyo objeto era cooperar y aunar esfuerzos técnicos, económicos y humanos para la identificación, valoración, inventario, protección, recuperación conservación, restauración, sostenibilidad y divulgación del patrimonio cultural mueble e inmueble declarado de interés cultural del ámbito nacional propiedad de la Iglesia católica. El fin primordial de este convenio era regular de manera específica el manejo y protección de los bienes culturales de la Iglesia, estableciendo un marco de cooperación institucional entre la Iglesia católica y el Estado colombiano para la 
protección, valoración y difusión del patrimonio cultural eclesial, el cual conservaría su naturaleza y finalidad religiosa, que no sería impedida por su valor cultural.

La implementación de este convenio permitió el conocimiento de los bienes, lo que llevó a generar mecanismos para protegerlos. Si se cumpliera la normatividad propia de la Iglesia con relación a la solicitud de la elaboración de inventarios, sería más fácil para la comisión mixta entre la CEC y el Ministerio de Cultura poder identificar los riesgos que afectan nuestro patrimonio religioso, puesto que nosotros mismos no conocemos qué bienes tenemos y, por ende, no los valoramos.

Lo anterior podría centralizarse si, aparte de la negociación en forma de convenios que se realiza entre cada persona jurídica de derecho público y el Estado colombiano, existiera un ente de carácter privado que ejerciese una veeduría en el cumplimiento del marco legislativo sobre los bienes de interés cultural y del patrimonio inmaterial (procesiones, etc.), que hoy es tan atacado en su catolicidad.

Este ente desarrollaría desde el derecho civil asesorías a los diferentes entes eclesiales sobre cuál es el manejo oportuno de estos bienes, buscando la aplicabilidad efectiva de estas normas, y desarrollando, por otra parte, modelos de inventario para las parroquias, con el fin de no perder el patrimonio cultural, representado no solo en las imágenes y objetos sagrados, sino también en los libros parroquiales, que constituyen un parámetro para toda la Iglesia colombiana.

\section{Referencias}

Benedicto XVI. (15 de junio de 2007). Discurso del Papa Benedicto XVI al congreso organizado por el Consejo Pontificio para la Cultura. Recuperado de http://w2.vatican.va/content/benedict-xvi/es/speeches/2007/june/ documents/hf_ben-xvi_spe_20070615_pc-cultura.html

Benedicto XVI. (30 de julio de 2012). Pulchritudinis Fidei. Recuperado de https://w2.vatican.va/content/benedict-x vi/la/motu_proprio/documents/hf_ben-xvi_motu-proprio_20120730_pulchritudinis-fidei.html

Código de Derecho Canónico (CIC). (1983). Recuperado de http://www.vatican.va/archive/ESL0020/_INDEX.H TM

Concordato entre la Repu\#blica de Colombia y la Santa Sede. (1973). Recuperado de https://www.cec.org.co/sites/d efault/files/WEB_CEC/Documentos/Documentos-Historicos/1973\%20Concordato\%201973.pdf

Constitución pastoral Gaudium et Spes. (1965). Recuperado de http://www.vatican.va/archive/hist_councils/ii_vati can_council/documents/vat-ii_const_19651207_gaudium-et-spes_sp.html

Fajardo de Rueda, M. (1999). El arte colonial neograndino a la luz del estudio iconográfico e iconológico. Bogotá: Convenio Andrés Bello.

Juan Pablo II. (1988). Constitución apostólica Pastor Bonus. Recuperado de http://w2.vatican.va/content/john-paul -ii/es/apost_constitutions/documents/hf_jp-ii_apc_19880628_pastor-bonus-index.html

Lleras Pérez, R. (2015). La producción del patrimonio cultural restaurado. Boletin de Historia y Antigüedades, 859.

Maymo\# i Capdevila, P. (2013). El ideario de lo sacro en Gregorio Magno (590-604): de los santos en la diplomacia pontificia (tesis de doctorado). Universidad de Barcelona, España. Recuperado de https://www.tdx.cat/bitstrea $\mathrm{m} /$ handle/10803/123278/PMC_TESIS.pdf;sequence $=1$

Monroy Cabra, M. (1986). Manual de derecho internacional público. Bogotá: Temis.

Organización de las Naciones Unidas para la Educación, la Ciencia y la Cultura (Unesco). (s. f.). Indicadores Unesco de cultura para el desarrollo: resumen analítico de Colombia. Recuperado de https://es.unesco.org/creativity/sites/ creativity/files/cdis/resumen_analitico_iucd___colombia_0_1.pdf

Pérez, R. (2020). La producción del patrimonio cultural restaurado. from La producción del patrimonio cultural restaurado | Lleras Pérez | Boletín de Historia y Antiguedades 859.

Pontificia Comisión para los Bienes culturales de la Iglesia. (2017). Recuperado de http://www.vatican.va/roman_cu $\mathrm{ria} /$ pontifical_commissions/pcchc/documents/rc_com_pcchc_pro_20051996_sp.html 
Pontificia Commissione per i Beni Culturali della Chiesa. (8 de diciembre de 1999). Lettera Circolare sulla necessit e urgenza dell inventariazione e catalogazione dei beni culturali della chiesa. Recuperado de http://www.vatican.va/roman_curia/pontifical_commissions/pcchc/documents/rc_com_pcchc_1999120 8_catalogazione-beni-culturali_it.html

Secretaría de Estado. (1 de septiembre de 1924). Carta circular a los Ordinarios de Italia, 1 de septiembre de 1924, prot. n. 34215 (pp. 196-198).

Secretaría de Estado. (2017). Annuarium Statisticum Ecclesiae 2017. Libreria Editrice Vaticana.

\section{Notas}

* Artículo de investigación

Licencia Creative Commons CC BY 4.0

Cómo citar este artículo: Flórez, S. L. (2018). Perspectivas jurídico-canónicas para la protección del patrimonio cultural eclesial en Colombia. Universitas Canónica, 35(51). https://doi.org/10.11144/Javeria na.ucan35-51.pjcp 